Original Research Paper

\title{
Crop Yield and Quality of Lentil Varieties in the Conditions of the Southeast of Kazakhstan
}

\author{
${ }^{1,2}$ Alma Zhumabaevna Saikenova, ${ }^{2}$ Mukhtar Sarsenbekovich Kudaibergenov, ${ }^{1}$ Taken Nurgassenovich \\ Nurgassenov, ${ }^{1}$ Bakytzhan Rakhmetolinovich Saikenov and ${ }^{2}$ Svetlana Vladimirovna Didorenko \\ ${ }^{1}$ Kazakh National Agrarian University, Almaty, Kazakhstan \\ ${ }^{2}$ Kazakh Research Institute of Agriculture and Plant Growing, Almalybak Village, Karasay District, Almaty Region, Kazakhstan
}

\author{
Article history \\ Received: 18-10-2020 \\ Revised: 23-01-2021 \\ Accepted: 25-01-2021 \\ Corresponding Author: \\ Alma Zhumabaevna Saikenova \\ Kazakh National Agrarian \\ University, Almaty, \\ Kazakhstan \\ And \\ Kazakh Research Institute of \\ Agriculture and Plant Growing, \\ Almalybak village, Karasay \\ district, Almaty Region, \\ Kazakhstan \\ Email: alma.arai@mail.ru
}

\begin{abstract}
The article presents the results of the three-year research aimed at studying and determining lentil varieties with high yields, suitable for mechanized harvesting (tall with the high attachment of lower beans), maturing at the same time and non-shedding, as well as resistant to stress factors, for use in breeding. The objectives of the research include the study of lentil varieties in two agro-ecological zones (in the conditions of semi-supplied dryland and the conditions of irrigation in the Southeast of Kazakhstan) with the establishment of vegetation periods; phenotyping of economically valuable features and properties; determination of lentil grain quality. Lentil varieties of different ecological and geographical origin (31 varieties) are used as material. They are distinguished from each other by their main economic and valuable features and biological properties. Phenological observations and assessments were carried out in two agroecological zones. Phenotyping of productivity elements was carried out according to the method of studying the collection of leguminous crops. The biochemical analysis determined the protein content in lentil grain. The authors of this article have identified the following varieties with high crop yield and protein content that are of interest for selection. All selected varieties will be used in the breeding process to create high-yielding, high quality and drought-resistant varieties.
\end{abstract}

Keywords: Gene Pool, Ggrain, Protein, Selection

\section{Introduction}

Lentil is a valuable food crop. It has a high nutritional value, traditionally replaces animal protein in the poor groups of the population and is becoming increasingly attractive as a major component of vegetarian diets in developed countries (Sarker et al., 2010; Vandenberg, 2011).

Currently, the problem of food and feed protein deficiency is becoming increasingly relevant in the international economy.

An increase in grain legume crop production is one of the main strategic tasks of agriculture in solving the provision of food security for the world's population. The protein problem should be solved mainly using grain legumes (Jarpa-Parra, 2018).

Lentil is one of the most widespread high-protein food grain legume crops. It is an important producer of biologically valuable digestible protein. Its content in the grains of different varieties amounts to $22 \ldots 36 \%$ (Pavlovskaya et al., 2010; Kostikova et al., 2010).

Lentil is a crop of versatile use: Food, feed and technical. It contains vitamins "A", "PP", "E", "B1", "B2", "B5", "B6", "B9" (folic acid) and beta-carotene. Its beans contain the amino acid tryptophan, which turns into serotonin in the human body, the so-called "vitamin of happiness". Lentil is a chain feedstock for the food and canning industry. Its grain waste and hay are an excellent feed for livestock (Vasko, 2018).

Lentil protein contains all essential amino acids (Thavarajah et al., 2011). In terms of lysine, phenylalanine, threonine and leucine content, lentil protein is similar to that of hen egg (Zotikov, 2010).

Lentil does not accumulate harmful and toxic elements, nitrates, or radionuclides. As a result, lentil grown anywhere in the world can be considered an ecofriendly product. 
A lentil plant, when interacting with bacteria rhizobia, is capable of fixing atmospheric nitrogen and at the same time enriching the soil with it; it belongs to the group of excellent precursors for many agricultural crops (Zotikov et al., 2016).

According to USDA, the leader in the harvesting of this crop is Canada (3,610,000 tons), followed by India (875,000 tons) and the USA (670,000 tons) (FAOSTAT, 2018).

Only five years ago lentil occupied no more than 6-7 thousand ha in Kazakhstan. According to predictions of the Ministry of Agriculture of Kazakhstan, in 2017, lentil was cultivated on an area of 200 thousand ha and in 2018, on 250 thousand ha. Currently, lentil is cultivated mainly in the northern regions of Kazakhstan (Abdullaev, 2018).

The average yield of lentil in the world is 11 centners per ha. The maximum yield is noted in China and Croatia 22 centners per ha. The average yield of lentil in Kazakhstan varies from 12.5 to 13.4 centners per ha (Gridneva and Kaliakparova, 2019).

In Kazakhstan, recently, the borders of sown areas for lentils have been expanding annually. It becomes profitable to produce it since its price is several times higher than that of wheat and demand for it is also growing (Aslanov, 2017).

According to (Mayorova and Sorokin, 1998), the stability of productivity in years different in meteorological conditions is very important for the breeding process. The results of testing lentil varieties indicate that a high seed yield can provide a genotype that not only has a high potential for productivity but also maximizes it regardless of external conditions.

Modern lentil varieties should not only produce consistently high yields but also have high-quality products (Guseinalidze, 2019).

The priority area of crop selection has been and remains the creation of new highly productive varieties. Lentil productivity is caused by the interaction of a complex of factors, of which the most important are such elements of yield structure as the number of beans, the number of seeds in the bean, the mass of seeds of the plant, the mass of 1,000 seeds. High productivity is a result of the most optimal combination of elements of its structure; therefore, it is necessary to pay attention to these features when selection on productivity is carried out (Kokhanyuk, 2014).

The increase in seed productivity is the main objective in most selection programs and this can be achieved by improving individual elements of the yield structure (Marakaeva, 2019). One of the available methods to evaluate plant productivity in the selection process is the identification of genotypes by quantitative features (Ivanyuk and Temchenko, 2011).
The success of selection depends on the correct choice of the initial material. Not all samples from the world collection are suitable for direct use in selection because of low productivity, ecological inadequacy, biological incompatibility and other negative properties. The involvement of such a source material in the selection process significantly extends it, which does not meet modern requirements (Gureeva and Fomina, 2016; Marakaeva, 2019; Saikenova et al., 2019).

The largest and most representative collection is concentrated in the International Center for Agricultural Research in the Dry Areas (ICARDA), which has an international mandate to develop the culture of lentils. Many of the lentil varieties cultivated in the world are lines from the ICARDA (Brennan et al., 2002).

The lack of interest in the cultivation of lentils among agricultural producers is due to the imperfection of most of the existing varieties. Among the main disadvantages is the low yield and manufacturability of existing varieties. The complexity of breeding lentils is determined by such biological characteristics of the crop as a relatively short stalk, low attachment of beans, lodging, poor competitiveness against weeds, low tolerance to herbicides, uneven ripening, cracking of beans and shattering of seeds, low resistance to biotic and abiotic stressors, etc.

Modern methods of molecular biology have shown that as a result of domestication, the amount of genetic diversity in lentils has decreased by approximately $40 \%$, which is also a negative factor for selection (Shpaar, 2000).

Due to the extensive use and value of lentils, it is necessary to expand lentil sowing area and production by studying and isolating original forms, stress-resistant to environmental factors and with high productivity in combination with the good quality of products for breeding.

The purpose of this work was to select the best lentilvarieties for use in breeding based on the following characteristics: Plant height, number of beans per plant, 1,000 seeds weight, yield, early maturity, protein content in the grain.

\section{Materials and Methods}

The study was conducted in 2017-2019 based on two types of land-irrigated arable land and semi-arid dryland (station of the Kazakh Research Institute of Agriculture and Plant Growing (KRIAPG), Almaty Region, Kazakhstan). The station of the KRIAPG is located in the submontane zone of Ile Alatau, the soil cover is represented by light brown loamy and less often sandy loamy soils. The content of humus reaches $3 \%$, group waters are found at the depth of 5 to $30 \mathrm{~m}$. Climatic conditions are characterized by mild, cool winter, cool spring, hot and dry summer, warm and dry autumn.

To characterize climatic conditions and describe their influence on the production process of lentils, the data of the meteorological station of the KRIAPG were used. 
Table 1: Average monthly air temperature and precipitation during the growing season, 2018

\begin{tabular}{|c|c|c|c|c|c|c|}
\hline \multirow[b]{2}{*}{ Month } & \multicolumn{3}{|c|}{ Temperature, ${ }^{\circ} \mathrm{C}$} & \multicolumn{3}{|c|}{ Precipitation, $\mathrm{mm}$} \\
\hline & Actual & Average long-term & Deviation & Actual & Average long-term & Deviation \\
\hline April & +12.4 & +10.4 & +2.0 & 81.6 & 56.5 & +25.1 \\
\hline May & +16.3 & +16.4 & -0.1 & 124.9 & 61.6 & +63.3 \\
\hline June & +22.3 & +21.2 & +1.1 & 28.7 & 53.9 & -25.2 \\
\hline July & +25.2 & +24.1 & +1.1 & 32.3 & 26.6 & +5.7 \\
\hline August & +24.5 & +22.1 & +2.4 & 43.5 & 21.3 & +22.2 \\
\hline
\end{tabular}

Agrometeorological conditions during the growing season in 2017-2019 were varied. 2018 was a favorable year for lentils.

When studying a collection of 1 running meter, the plots have 25 seeds. Harvesting was carried out according to the methods described in the field experiment method of (Dospekhov, 2012). Agrotechnics in the experiments was carried out according to methodological recommendations for the south-east of Kazakhstan (Kudaibergenov and Didorenko, 2014).

The sowing was randomized in triplicate. The objects of the study included 31 varieties of lentils from different countries of the world, one standard per 10 pcs. Vehovskaya variety was used as a standard, which is located in Kazakhstan and allowed for use in the NorthKazakhstan and Kostanay regions.

Phenological observations (sowing, seedling, flowering, ripening), visual assessment was carried out in two zones in accordance with the "Methodological guidelines for studying the collection of leguminous crops" (Vishnyakova et al., 2010).

Phenotyping of productivity elements (height of the plant, cm-stem length from the soil surface to the top; the height of the lower bean attachment, cm-stem length from the soil surface to the first bean attachment; the number of productive nodes, pcs the number of nodes carrying during bean ripening; the number of beans on the plant, pcs the number of beans on the plant; the weight of seeds from the plant, g, the weight of 1,000 seeds, g) were carried out according to methodical guidelines for the study of a grain legume collection.

Harvesting in two areas was done manually as the varieties ripened.

Protein content was determined according to Kjeldahl (GOST 10846-91. "Grain and its processed products. Method for protein determination"). Sampling for protein determination was carried out in accordance with GOST 10852-86. (Acceptance rules and sampling methods for "Oilseeds"). A sample weighing $100 \mathrm{~g}$ was taken from a volume of $1 \mathrm{~kg}$ with three field reps. The average protein content of the nurseries was calculated for each year.

Analysis of these productivity indicators was carried out using Statistica 10 software (portable version).

\section{Results}

When studying the phenological phases of the development of the collection of the lentil samples, it was noted that large-seeded varieties on irrigation had a longer growing season than in the absence of irrigation for 8-10 days. Moreover, the lengthening of the growing season was mainly due to the lengthening of the filling phase of beans-ripening in all years of the study (Fig. 1).

The collection material was grouped by seed size into large-seeded and small-seeded varieties.

Growing conditions (irrigation and dryland) influenced all characteristics of productivity of both large-seeded and small-seeded varieties. Thus, on dryland in both groups, the plant height decreased by an average of $10.7 \mathrm{~cm}$ in the large-seeded group and by $12.2 \mathrm{~cm}$ in the small-seeded group of varieties.

The number of beans per plant on irrigation in smallseeded cultivars was higher than in large-seeded (55.9 \pm 4.1 and $38.1 \pm 2.8$, respectively). On dryland, the number of beans per plant in both groups decreased; the absence of irrigation had a greater effect on the smallseeded group. Thus, on dryland, the indicator of the number of seeds per plant in large-seeded and smallseeded plants was at the same level $(25.3 \pm 2.7$ and $29.7 \pm 2.4$, respectively). The absence of irrigation also affected the weight of 1,000 seeds. The decrease in the two groups was not equivalent: To $22 \%$ in large-seeded and $14.8 \%$ in small-seeded varieties (Table 2).

The growing season on irrigation in the group of large-seeded varieties was 8-10 days longer than in small-seeded varieties $(85.7 \pm 1.9$ days and $77.8 \pm 2.9$ days, respectively). The absence of irrigation led to a reduction in the growing season in the large-seeded group of accessions by an average of 11 days, while in the smallseeded samples, the growing season decreased by only 3 days and amounted to $75.3 \pm 2.5$ days.

The yield was highly correlated with the number of beans per plant. Thus, the most productive on irrigation were small-seeded samples $(15.3 \pm 1.4 \mathrm{c} / \mathrm{ha})$, while largeseed samples on irrigation showed an average yield of $7.7 \pm 1.6 \mathrm{c} / \mathrm{ha}$.

The absence of irrigation almost halved the yield in the small-seeded group to $7.0 \pm 0.8 \mathrm{c} / \mathrm{ha}$; the absence of irrigation in the large-seeded group did not significantly affect the yield.

The protein content in the small-seeded group was higher than that in the large-seeded group and on irrigation was $34.9 \pm 1.4 \%$ and $32.2 \pm 2.3 \%$, respectively.

The protein content both on irrigation and dryland in the two groups was at the same level (Table 3). 
Alma Zhumabaevna Saikenova et al. / OnLine Journal of Biological Sciences 2021, 21 (1): 33.40 DOI: 10.3844/ojbsci.2021.33.40

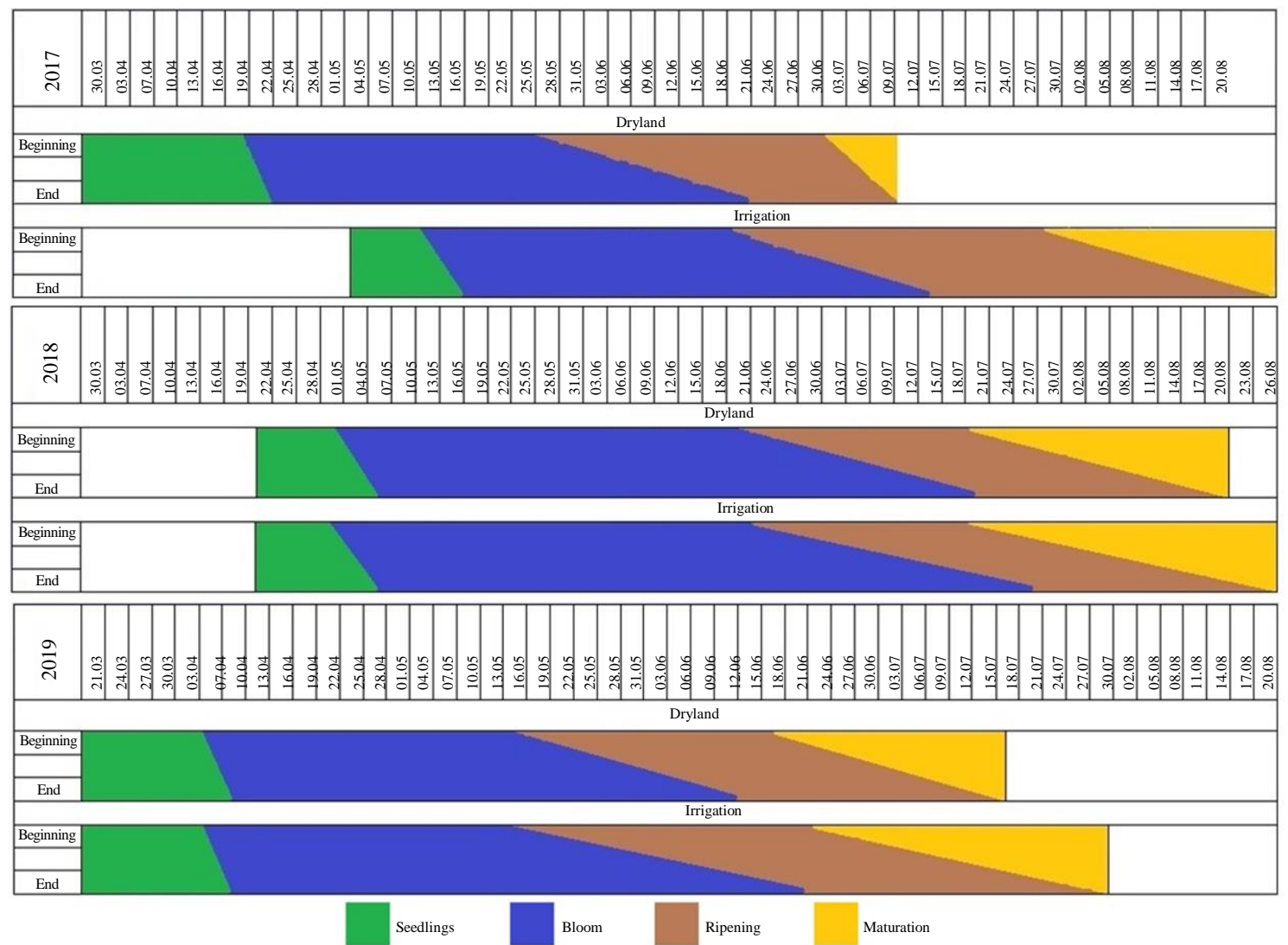

Fig. 1: Phenospectra of large-seeded lentil cultivar K-184 (2017-2019)

Table 2: Indicators of productivity traits of collection varieties of lentils on irrigation and dryland

\begin{tabular}{|c|c|c|c|c|c|c|}
\hline \multirow[b]{2}{*}{ Breeding number } & \multicolumn{2}{|l|}{ Height, $\mathrm{cm}$} & \multicolumn{2}{|c|}{ Number of beans per plant, pcs } & \multicolumn{2}{|c|}{ Weight of 1.000 seeds, g } \\
\hline & Irrigation & Dryland & Irrigation & Dryland & Irrigation & Dryland \\
\hline \multicolumn{7}{|l|}{ Large-seeded } \\
\hline Vehovskaya standard & $50.4 \pm 2.0$ & $33.4 \pm 2.2$ & $26.2 \pm 2.8$ & $25.6 \pm 2.6$ & $73.5 \pm 3.3$ & $57.7 \pm 2.2$ \\
\hline LC04600017L & $26.4 \pm 2.5$ & $24.1 \pm 1.2$ & $52.7 \pm 3.7$ & $27.7 \pm 3.1$ & $46.6 \pm 2.3$ & $39.5 \pm 0.7$ \\
\hline LC046000246L & $44.1 \pm 3.1$ & $37.1 \pm 2.3$ & $28.6 \pm 2.2$ & $24.0 \pm 2.5$ & $75.0 \pm 2.8$ & $55.1 \pm 1.3$ \\
\hline LC04600068L & $42.7 \pm 1.1$ & $35.8 \pm 4.2$ & $54.0 \pm 6.9$ & $32.4 \pm 2.9$ & $62.4 \pm 3.2$ & $54.7 \pm 0.9$ \\
\hline LC046000150L & $44.4 \pm 1.0$ & $36.2 \pm 3.8$ & $36.3 \pm 3.9$ & $19.7 \pm 0.9$ & $49.1 \pm 1.1$ & $51.9 \pm 8.8$ \\
\hline K-6 & $50.8 \pm 1.1$ & $36.7 \pm 0.5$ & $42.7 \pm 2.8$ & $19.7 \pm 1.1$ & $74.4 \pm 4.1$ & $47.8 \pm 1.8$ \\
\hline LC04600023L & $52.1 \pm 1.5$ & $36.7 \pm 4.1$ & $23.5 \pm 5.1$ & $24.1 \pm 3.5$ & $73.9 \pm 3.5$ & $55.5 \pm 1.6$ \\
\hline 39227 & $49.6 \pm 0.7$ & $34.0 \pm 1.5$ & $29.2 \pm 2.4$ & $23.2 \pm 3.7$ & $76.9 \pm 1.1$ & $56.3 \pm 2.9$ \\
\hline LC046000202L & $43.0 \pm 3.4$ & $35.4 \pm 1.3$ & $37.3 \pm 1.4$ & $20.3 \pm 2.3$ & $77.2 \pm 2.5$ & $57.3 \pm 3.2$ \\
\hline LC04600010L & $50.4 \pm 1.8$ & $36.9 \pm 4.5$ & $33.2 \pm 1.8$ & $21.8 \pm 1.5$ & $70.7 \pm 1.2$ & $54.8 \pm 1.8$ \\
\hline 39126 & $43.8 \pm 1.3$ & $35.5 \pm 4.2$ & $41.9 \pm 1.3$ & $26.2 \pm 2.7$ & $66.7 \pm 1.4$ & $54.2 \pm 2.1$ \\
\hline 23209 & $51.7 \pm 1.9$ & $36.9 \pm 2.8$ & $27.0 \pm 1.6$ & $22.9 \pm 2.8$ & $69.9 \pm 2.0$ & $55.3 \pm 1.6$ \\
\hline LC046000103L & $42.6 \pm 1.2$ & $34.9 \pm 4.5$ & $37.2 \pm 2.1$ & $25.6 \pm 2.3$ & $84.3 \pm 4.0$ & $58.1 \pm 3.6$ \\
\hline K-184 & $45.8 \pm 1.3$ & $35.1 \pm 1.3$ & $62.8 \pm 3.3$ & $30.4 \pm 2.9$ & $46.2 \pm 2.6$ & $44.5 \pm 1.4$ \\
\hline 23208 & $35.0 \pm 1.9$ & $34.0 \pm 1.3$ & $68.5 \pm 5.9$ & $40.1 \pm 2.0$ & $46.9 \pm 1.0$ & $41.5 \pm 1.1$ \\
\hline LC046000156L & $41.9 \pm 1.5$ & $35.4 \pm 2.4$ & $28.2 \pm 1.4$ & $25.3 \pm 1.3$ & $76.2 \pm 19.6$ & $54.1 \pm 2.5$ \\
\hline 23202 & $47.4 \pm 1.0$ & $36.4 \pm 2.8$ & $24.8 \pm 3.1$ & $12.4 \pm 1.4$ & $68.3 \pm 1.7$ & $54.8 \pm 2.0$ \\
\hline 4605 & $51.0 \pm 1.8$ & $36.2 \pm 3.8$ & $33.7 \pm 1.6$ & $20.0 \pm 3.2$ & $94.5 \pm 4.0$ & $59.4 \pm 5.1$ \\
\hline LC046000170L & $42.7 \pm 3.0$ & $34.2 \pm 2.1$ & $25.2 \pm 1.6$ & $24.3 \pm 1.5$ & $75.5 \pm 4.0$ & $56.8 \pm 3.6$ \\
\hline LC046000270L & $50.8 \pm 2.8$ & $34.5 \pm 2.1$ & $23.9 \pm 1.7$ & $20.5 \pm 2.8$ & $66.9 \pm 2.9$ & $58.1 \pm 4.0$ \\
\hline LC046000213L & $53.3 \pm 1.6$ & $35.8 \pm 2.9$ & $27.7 \pm 0.9$ & $17.5 \pm 1.9$ & $69.2 \pm 3.4$ & $57.4 \pm 4.3$ \\
\hline K-2849 & $53.7 \pm 1.2$ & $35.6 \pm 4.4$ & $43.5 \pm 3.1$ & $27.2 \pm 3.8$ & $70.3 \pm 2.0$ & $56.7 \pm 4.6$ \\
\hline LC046000223L & $38.6 \pm 1.3$ & $36.3 \pm 0.4$ & $45.1 \pm 4.3$ & $46.0 \pm 8.6$ & $65.4 \pm 2.9$ & $25.9 \pm 5.4$ \\
\hline 39119 & $51.9 \pm 1.6$ & $37.4 \pm 3.9$ & $48.2 \pm 2.2$ & $27.2 \pm 3.6$ & $49.4 \pm 1.5$ & $49.4 \pm 3.0$ \\
\hline
\end{tabular}


Table 2: Continue

\begin{tabular}{lllllll}
\hline 31215 & $49.3 \pm 1.8$ & $36.9 \pm 3.2$ & $31.7 \pm 2.2$ & $29.5 \pm 1.6$ & $68.3 \pm 2.7$ & $60.1 \pm 0.8$ \\
K-1975 & $40.4 \pm 0.8$ & $34.9 \pm 2.1$ & $56.6 \pm 3.7$ & $23.8 \pm 2.8$ & $64.6 \pm 2.1$ & $56.6 \pm 0.5$ \\
$\begin{array}{l}\text { Average } \\
\text { Small-seeded }\end{array}$ & $\mathbf{4 5 . 9} \pm \mathbf{1 . 7}$ & $\mathbf{3 5 . 2} \pm \mathbf{2 . 7}$ & $\mathbf{3 8 . 1} \pm \mathbf{2 . 8}$ & $\mathbf{2 5 . 3} \pm \mathbf{2 . 7}$ & $\mathbf{6 7 . 8} \pm \mathbf{3 . 2}$ & $\mathbf{5 2 . 8 \pm 2 . 7}$ \\
23108 & & & & & & \\
K-2017 & $38.5 \pm 1.2$ & $35.2 \pm 3.6$ & $57.8 \pm 1.8$ & $37.3 \pm 1.6$ & $30.7 \pm 2.1$ & $22.9 \pm 2.8$ \\
39229 & $49.0 \pm 2.8$ & $34.2 \pm 2.1$ & $53.1 \pm 3.1$ & $24.1 \pm 1.5$ & $38.5 \pm 0.7$ & $33.7 \pm 2.0$ \\
39113 & $52.8 \pm 2.8$ & $35.0 \pm 3.8$ & $65.6 \pm 7.9$ & $14.8 \pm 2.8$ & $32.0 \pm 3.5$ & $26.0 \pm 3.5$ \\
39203 & $45.6 \pm 1.1$ & $36.3 \pm 5.2$ & $40.7 \pm 4.5$ & $29.2 \pm 2.2$ & $30.2 \pm 1.7$ & $27.5 \pm 1.9$ \\
Average & $50.5 \pm 0.9$ & $34.5 \pm 0.9$ & $\mathbf{6 2 . 1} \pm 3.4$ & $28.1 \pm 3.9$ & $30.8 \pm 2.8$ & $28.1 \pm 3.9$ \\
\hline
\end{tabular}

Table 3: Yield and quality indicators of collection varieties of lentils on irrigation and dryland

\begin{tabular}{|c|c|c|c|c|c|c|}
\hline \multirow[b]{2}{*}{ Breeding number } & \multicolumn{2}{|c|}{ Vegetation period, days } & \multicolumn{2}{|c|}{ Productivity, c/ha } & \multicolumn{2}{|l|}{ Protein, $\%$} \\
\hline & Irrigation & Dryland & Irrigation & Dryland & Irrigation & Dryland \\
\hline \multicolumn{7}{|l|}{ Large-seeded } \\
\hline Vehovskaya standard & $86.5 \pm 1.7$ & $75.0 \pm 2.0$ & $5.3 \pm 2.2$ & $4.1 \pm 2.0$ & $31.0 \pm 1.8$ & $31.2 \pm 1.8$ \\
\hline LC04600017L & $80.0 \pm 1.0$ & $75.3 \pm 2.5$ & $4.5 \pm 0.8$ & $2.2 \pm 0.5$ & $31.7 \pm 1.4$ & $33.6 \pm 0.6$ \\
\hline $\mathrm{LC} 046000246 \mathrm{~L}$ & $85.8 \pm 1.3$ & $77.3 \pm 2.5$ & $5.2 \pm 1.9$ & $6.5 \pm 0.6$ & $31.5 \pm 0.2$ & $31.1 \pm 2.1$ \\
\hline LC04600068L & $78.3 \pm 3.1$ & $75.7 \pm 3.1$ & $9.7 \pm 1.4$ & $9.2 \pm 0.8$ & $34.9 \pm 0.5$ & $35.1 \pm 1.6$ \\
\hline LC046000150L & $85.8 \pm 1.3$ & $75.7 \pm 3.1$ & $5.5 \pm 0.7$ & $3.6 \pm 0.8$ & $31.4 \pm 3.5$ & $32.1 \pm 1.8$ \\
\hline $\mathrm{K}-6$ & $87.1 \pm 2.0$ & $75.7 \pm 3.1$ & $7.2 \pm 1.6$ & $6.6 \pm 1.0$ & $31.4 \pm 1.5$ & $32.3 \pm 2.2$ \\
\hline LC04600023L & $98.1 \pm 3.0$ & $77.3 \pm 2.5$ & $5.5 \pm 1.9$ & $5.8 \pm 0.9$ & $33.1 \pm 2.6$ & $32.3 \pm 1.1$ \\
\hline 39227 & $94.4 \pm 2.2$ & $77.7 \pm 3.1$ & $5.8 \pm 0.7$ & $3.8 \pm 0.9$ & $31.3 \pm 2.9$ & $32.5 \pm 0.4$ \\
\hline LC046000202L & $85.8 \pm 1.3$ & $77.3 \pm 2.5$ & $6.7 \pm 1.6$ & $7.5 \pm 1.9$ & $30.3 \pm 1.8$ & $30.4 \pm 2.4$ \\
\hline LC04600010L & $83.8 \pm 1.3$ & $77.3 \pm 2.5$ & $5.9 \pm 1.6$ & $5.0 \pm 1.5$ & $30.7 \pm 3.2$ & $31.5 \pm 0.8$ \\
\hline 39126 & $80.0 \pm 1.0$ & $75.7 \pm 3.1$ & $12.4 \pm 2.3$ & $6.0 \pm 1.0$ & $33.3 \pm 1.6$ & $30.3 \pm 1.6$ \\
\hline 23209 & $91.1 \pm 1.7$ & $77.3 \pm 2.5$ & $7.0 \pm 2.8$ & $7.7 \pm 2.0$ & $30.8 \pm 3.7$ & $31.9 \pm 2.7$ \\
\hline LC046000103L & $85.1 \pm 2.2$ & $75.7 \pm 3.1$ & $13.0 \pm 0.7$ & $9.5 \pm 2.5$ & $32.3 \pm 3.7$ & $31.0 \pm 1.7$ \\
\hline K-184 & $80.0 \pm 1.0$ & $75.3 \pm 2.5$ & $16.7 \pm 0.9$ & $5.9 \pm 1.4$ & $32.9 \pm 3.5$ & $32.9 \pm 0.4$ \\
\hline 23208 & $80.0 \pm 1.0$ & $75.0 \pm 2.0$ & $7.5 \pm 4.2$ & $7.2 \pm 3.2$ & $36.6 \pm 0.3$ & $36.0 \pm 0.1$ \\
\hline LC046000156L & $83.8 \pm 1.3$ & $76.7 \pm 2.9$ & $9.2 \pm 1.7$ & $4.1 \pm 1.9$ & $33.2 \pm 3.1$ & $32.0 \pm 2.5$ \\
\hline 23202 & $94.4 \pm 2.2$ & $75.3 \pm 2.5$ & $5.7 \pm 0.5$ & $3.6 \pm 1.3$ & $35.5 \pm 0.2$ & $34.4 \pm 0.0$ \\
\hline 4605 & $80.0 \pm 1.0$ & $77.0 \pm 3.5$ & $7.1 \pm 2.5$ & $6.9 \pm 0.9$ & $33.6 \pm 4.0$ & $31.9 \pm 0.1$ \\
\hline LC046000170L & $91.2 \pm 1.6$ & $76.0 \pm 3.6$ & $5.2 \pm 2.8$ & $7.5 \pm 0.7$ & $32.4 \pm 2.3$ & $31.6 \pm 3.4$ \\
\hline LC046000270L & $91.2 \pm 1.6$ & $76.0 \pm 3.6$ & $9.8 \pm 1.2$ & $3.9 \pm 2.3$ & $31.7 \pm 5.2$ & $31.2 \pm 2.2$ \\
\hline LC046000213L & $80.0 \pm 1.0$ & $76.0 \pm 3.6$ & $5.0 \pm 1.1$ & $3.8 \pm 1.0$ & $32.5 \pm 2.1$ & $33.1 \pm 2.8$ \\
\hline K-2849 & $98.0 \pm 3.0$ & $76.0 \pm 3.6$ & $6.3 \pm 2.2$ & $6.9 \pm 1.2$ & $31.0 \pm 2.6$ & $33.0 \pm 1.9$ \\
\hline LC046000223L & $77.7 \pm 3.1$ & $75.3 \pm 2.5$ & $13.3 \pm 1.9$ & $13.7 \pm 2.7$ & $29.9 \pm 2.5$ & $32.2 \pm 4.0$ \\
\hline 39119 & $78.3 \pm 3.1$ & $76.0 \pm 3.6$ & $7.9 \pm 1.1$ & $5.3 \pm 1.1$ & $30.5 \pm 1.8$ & $29.3 \pm 2.6$ \\
\hline 31215 & $94.4 \pm 2.2$ & $75.3 \pm 2.5$ & $6.8 \pm 0.7$ & $5.3 \pm 1.5$ & $32.6 \pm 2.6$ & $33.0 \pm 2.3$ \\
\hline K-1975 & $78.3 \pm 3.1$ & $75.7 \pm 3.1$ & $6.8 \pm 0.8$ & $3.3 \pm 1.2$ & $32.1 \pm 2.3$ & $34.3 \pm 0.1$ \\
\hline Average & $85.7 \pm 1.9$ & $76.1 \pm 2.9$ & $7.7 \pm 1.6$ & $6.0 \pm 1.4$ & $32.2 \pm 2.3$ & $32.3 \pm 1.7$ \\
\hline \multicolumn{7}{|l|}{ Small-seeded } \\
\hline 23108 & $77.0 \pm 2.0$ & $75.0 \pm 2.0$ & $18.4 \pm 1.7$ & $9.5 \pm 0.8$ & $36.7 \pm 0.8$ & $36.4 \pm 0.5$ \\
\hline K-2017 & $78.4 \pm 3.2$ & $75.7 \pm 3.1$ & $8.5 \pm 2.2$ & $6.0 \pm 0.6$ & $37.0 \pm 0.8$ & $36.2 \pm 0.1$ \\
\hline 39229 & $77.0 \pm 3.5$ & $75.3 \pm 2.5$ & $16.7 \pm 0.6$ & $9.3 \pm 0.4$ & $32.3 \pm 2.7$ & $34.0 \pm 0.4$ \\
\hline 39113 & $78.3 \pm 3.1$ & $75.0 \pm 2.0$ & $16.7 \pm 1.2$ & $3.6 \pm 1.6$ & $36.7 \pm 1.1$ & $36.8 \pm 1.3$ \\
\hline 39203 & $78.3 \pm 3.1$ & $75.7 \pm 3.1$ & $16.1 \pm 1.5$ & $6.6 \pm 0.7$ & $31.6 \pm 1.4$ & $32.7 \pm 0.1$ \\
\hline Average & $77.8 \pm 2.9$ & $75.3 \pm 2.5$ & $15.3 \pm 1.4$ & $7.0 \pm 0.8$ & $34.9 \pm 1.4$ & $35.2 \pm 0.5$ \\
\hline
\end{tabular}

\section{Discussion}

In the study by scientists from (Amirov et al., 2017), small-seeded varieties exceed large-seeded varieties in terms of protein content, which was confirmed in the present study.

According to the results of the assessment by economically valuable traits in contrasting growing conditions, the best samples of lentils were identified.
By plant height; the following were distinguished: 39119, 23209, LC04600010L, 31215, LC04600023L and K-6 with an indicator of 50.37-53.67 cm for irrigation and $36.70-37.70 \mathrm{~cm}$ for dryland.

By the number of beans per plant, the following were distinguished: The LC04600068L, 23108, 23208 and LC046000223L varieties with an indicator of $31.67-68.53$ pcs on irrigation and 30.37-46.03 pes on dryland. 
Table 4: Distinguished samples of lentils based on productivity characteristics under different growing conditions

\begin{tabular}{llll}
\hline & Indices & & \\
Features & In the conditions of irrigation & Semi-supplied dryland & Samples \\
\hline Height of plants & $50.37-53.67 \mathrm{~cm}$ & $36.70-37.70 \mathrm{~cm}$ & $39119,23209, \mathrm{LC} 04600010 \mathrm{~L}$, \\
Number of beans & $31.67-68.53$ & $30.37-46.03$ & $31215, \mathrm{LC} 04600023 \mathrm{~L}, \mathrm{~K}-6$ \\
on the plant & & & LC04600068L, 23108, \\
Weight of 1,000 seeds & Large-seeded & Large-seeded & 23208, LC046000223L \\
& $62.40-94.47 \mathrm{~g}$ & $57.67-60.13 \mathrm{~g}$ & Vehovskaya, 31215, 4605, \\
& Small-seeded & Small-seeded & LC046000103L, LC046000270L \\
& $32.0-38.47 \mathrm{~g}$ & $27.47-33.73 \mathrm{~g}$ & K-2017 \\
Yield & Large-seeded & Large-seeded & LC046000223L, \\
1 & $6.70-9.20 \mathrm{c} / \mathrm{ha}$ & $9.47-9.30 \mathrm{c} / \mathrm{ha}$ & LC046000103L, LC04600068L \\
& Small-seeded & Small-seeded & \\
Protein & $18.37-16.13 \mathrm{c} / \mathrm{ha}$ & $16.70-9.20 \mathrm{c} / \mathrm{ha}$ & 23108,39229 \\
& Large-seeded & Large-seeded & \\
& $34.94-36.65 \%$ & $34.4-36.0 \%$ & $23208,23202, \mathrm{LC} 04600068 \mathrm{~L}$ \\
& Small-seeded & Small-seeded & \\
& $36.71-37.05 \%$ & $36.15-36.75 \%$ & K-2017, 23108, 39113 \\
\hline
\end{tabular}

By the weight of 1,000 seeds in the large-seeded group, the following were distinguished: The Vehovskaya standard, 31215, 4605, LC046000103L and LC046000270L varieties with an indicator of $62.40-94.47 \mathrm{~g}$ on irrigation and 57.67-60.13 $\mathrm{g}$ on dryland. In the small-seeded group, one cultivar stood out: K-2017 with an indicator of 32.0-38.47 $\mathrm{g}$ for irrigation and 9.47-9.30 $\mathrm{g}$ for dryland.

By the yield in the large-seeded group, the following stood out: LC046000223L, LC046000103L and LC04600068L with an indicator for irrigation of 16.70-9.20 c/ha and dryland 9.47-9.30 c/ha. In the small-seeded group, the following stood out: 23108 and 39229 with an indicator on irrigation of 18.37-16.13 c/ha and dryland 16.70-9.20 c/ha.

Samples with a high protein index in the large-seeded group (34.94-36.65\%) stood out: 23208, 23202 and LC04600068L; in the small-seeded group, we noted K2017, 23108 and 39113 (36.71-37.05\%) (Table 4).

\section{Conclusion}

The main issue of selection is the identification of sources of economically valuable properties and their involvement in the selection process, with planning of parental pairs for crossbreeding and prediction of the selection effectiveness in hybrid populations.

Following the purpose of the study, we selected the following lentil varieties:

- By plant height: 39119, 23209, LC04600010L, 31215, LC04600023L, K-6

- By number of beans on the plant: LC04600068L, 23108, 23208, LC046000223L
- By weight of 1,000 seeds: Vehovskaya, 31215, 4605, LC046000103L, LC046000270L, K-2017

- By yield: LC046000223L, LC046000103L, LC04600068L, 23108, 39229

- By early maturity: LC04600068L, LC046000223L, 39119, K-1975, 23108, K-2017, 39229, 39113, 39203

- By high protein index: 23208, 23202, K-2017, 23108, 39113

\section{Acknowledgment}

The authors received no financial support for the research.

\section{Author's Contributions}

All authors contributed equally.

\section{Ethics}

This article is original and contains unpublished material. The corresponding author confirms that all of the other authors have read and approved the manuscript and no ethical issues involved.

\section{References}

Abdullaev, K. (2018). Chechevitsa. Novye vozmozhnosti dlya agrariev [Lentil. New opportunities for farmers], Apgazeta.kz.

Amirov, L. A., Guseinov, S. I., Gasanova, G. M., \& Mirzoev, R. S. (2017). Kachestvo zerna prodovolstvennykh bobovykh kultur nuta i chechevitsy v usloviyakh Azerbaidzhana [Grain quality of food legumes of chickpea and lentil in Azerbaijan]. Vestnik nauki i obrazovaniya, 2(26), 10-12. 
Aslanov, V. (2017). Chechevitsa - nishevaya zhila dlya kazakhstanskikh fermerov? [Lentils - a Niche Avenue for Kazakhstani Farmers?]

Brennan, J. P., Aw-Hassan, A., Quade, K. J., \& Nordblom, T. L. (2002). Impact of ICARDA research on Australian agriculture (No. 1160-2016-93028).

Dospekhov, B. A. (2012). Metodika polevogo opyta (s osnovami statististicheskoy obrabotki rezultatov issledovaniy) [Methodology of field experiment (with the basics of statistical processing of research results)]. Kniga po Trebovaniyu, Moscow, pp. 352.

FAOSTAT. (2018). Prodovolstvennaya i selskokhozyaistvennaya organizatsiya Obedinennykh Natsii [Food and Agriculture Organization of the United Nations].

Gridneva, E. E., \& Kaliakparova, G. S. (2019). Tendentsii razvitiya mirovogo rynka nishevykh kultur: rapsa, lna, chechevitsy [Trends in the world market of niche crops: rapeseed, flax and lentil]. Problemy agrorynka, 3: 148-153.

Gureeva, E. V., \& Fomina, T. A. (2016). Otsenka kollektsionnykh obraztsov soi kak iskhodnogo materiala dlya selektsii [Evaluation of collected soybean samples as a source material for selection]. Zernobobovye i krupyanye kultury, 1(17): 40-45.

Guseinalidze, U. R. (2019). Svyaz mezhdu urozhainostyu i kachestvom zerna v sortoobraztsakh chechevitsy obyknovennoi (Lens Culinaris Medik) [Relationship between crop yield and grain quality in lentil varieties (Lens Culinaris Medik)]. Vestnik nauki i obrazovaniya, 9(63): 5-10.

Ivanyuk, S. V., \& Temchenko, I. V. (2011). Matematikostatistichni metodi otsinki vikhidnogo materialu soi za elementami produktivnosti [Mathematicalstatistical method for the evaluation of the final soybean content by productivity elements]. Kormi i kormovirobnitstvo, 69: 45-53.

Jarpa-Parra, M. (2018). Lentil protein: a review of functional properties and food application. An overview of lentil protein functionality. International Journal of Food Science \& Technology, 53(4), 892-903.

Kokhanyuk, N. V. (2014). Otsinka zrazkiv soi na osnovi korelyatsii kilkisnikh oznak ta indeksiv [Evaluation of soybean samples via correlation of quantitative data and indices]. Selektsiya i nasinnitstvo, 106: 71-76.

Kostikova, N. O., Uvarova, O. V., \& Yanova, A. A. (2010). Kachestvo zerna sortov chechevitsy novogo pokoleniya [Grain quality of new generation of lentil varieties]. Proceedings of the All-Russian conference third readings dedicated to the memory of Professor Stepan Ivanovich Efremov "Modern aspects of structural and functional biology of plants and fungi", September 23-25, GOU VPO "OGU", Orel, pp: 140-142.
Kudaibergenov, M. S., \& Didorenko, S. V. (2014). Tekhnologiya vozdelyvaniya soi na oroshayemykh zemlyakh yugo-vostoka Kazakhstana [Technology of soybeancultivation on irrigated lands in the southeast of Kazakhstan]. Asyl kitap, pp. 24.

Mayorova, M. M., \& Sorokin, S. I. (1998). Razrabotka kriteriyev otsenki selektsionnogo materiala tarelochnoy chechevitsy [Development of criteria for evaluating breeding material for plate lentils]. Sovremennoye sostoyaniye i perspektivy razvitiya selektsii i semenovodstva selskokhozyaystvennykh kultur v Rossiyskoy Federatsii: sb. statey Vserossiyskoy nauchno-prakticheskoy konferentsii. Chast 1 [Current state and prospects for the development of selection and seed production of agricultural crops in the Russian Federation: a collection of articles of the All-Russian scientificpractical conference. Part 1]. Privolzhskiy dom znaniy, Penza. Pp. 74-75.

Marakaeva, T. V. (2019). Iskhodnyi material dlya selektsii chechevitsy v Omskoi oblasti [Source Material for Lentil Breeding in Omsk Region]. Elektronnyi nauchno metodicheskii zhurnal Omskogo GAU, 2 (17).

Pavlovskaya, N. E., Zotikov, V. I., \& Kornienko, N. N. (2010). Biokhimiya zernobobovykh i krupyanykh kultur [Biochemistry of legumes and cereals]. Publishing house of Orel GAU, Orel. ISBN: 978-593382-158-8, pp: 299.

Saikenova, A. Z., Nurgasenov, T. N., Saikenov, B. R., Kudaibergenov, M. S., \& Vacic, M. (2019). Source material for lentil selection in the conditions of South-east Kazakhstan. Ecology, Environment and Conservation, 25(2), 729-735.

Sarker, A., Singh, M., Rajaram, S., \& Erskine, W. (2010). Adaptation of Small-Seeded Red Lentil (Lens culinaris Medik. subsp. culinaris) to Diverse Environments. Crop science, 50(4), 1250-1259.

Shpaar, D. (2000). [Legumes]. FUA-inform, Minsk, pp. 264.

Thavarajah, D., Thavarajah, P., Wejesuriya, A., Rutzke, M., Glahn, R., Combs, G., \& Vandenberg, A. (2011). The potential of lentil (Lens culinaris L.) as a whole food for increased selenium, iron, and zinc intake: preliminary results from a 3 year study. Euphytica, $180,123-128$.

Vandenberg, B. (2011). Lentils-the little seeds with the big impact on human health. Grain Legumes, (57), 25-26.

Vasko, V. T. (2018). Osnovy semenovedeniya polevykh kultur: ucheb. Posobie [Basic field crop seed studies: a textbook]. Lan, St. Petersburg. ISBN: 9785-8114-1111-5, pp: 301. 
Vishnyakova, M. A., Buravtseva, T. V., \& Bulyntsev, S. V. (2010). Kollektsiya mirovykh geneticheskikh resursov zernovykh bobovykh VIR: popolnenie, sokhranenie i izuchenie: metod. ukaz. [Collection of world genetic resources of grain legumes of the All-Union Research Institute of Plant Breeding: replenishment, preservation and study: guidelines]. VIR, Saint Petersburg. ISBN: 978-5-905954-79-5, pp: 143.

Zotikov, V. I. (2010). Zernobobovye kultury - istochnik rastitelnogo belka [Legumes - source of plant protein]. GNU VNIIZBK, Orel. ISBN: 978-5904678-02-9, pp: 268.
Zotikov, V. I., Naumkina, T. S., Gryadunova, N. V., Sidorenko, V. S., \& Naumkin, V. V. (2016). Zernobobovye kultury-vazhnyi faktor ustoichivovgo ekologicheski orientirovannogo selskogo khozyaistva [Grain legumes - important factor of sustainable ecologically oriented agriculture]. Zernobobovye i krupyanye kultury, 1(17): 6-13. 